\title{
Retraction
}

\section{Retracted: New 1,2,3-Triazole Iminosugars Derivatives Using Click Chemistry}

\section{International Journal of Carbohydrate Chemistry}

Received 22 December 2014; Accepted 22 December 2014; Published 31 December 2014

Copyright ( 2014 International Journal of Carbohydrate Chemistry. This is an open access article distributed under the Creative Commons Attribution License, which permits unrestricted use, distribution, and reproduction in any medium, provided the original work is properly cited.

This article has been retracted as it was submitted for publication without the prior knowledge or approval of Dr. Aloysius Siriwardena, who has contributed to the article. Additionally, it has been submitted without prior approval of the Centre National de la Recherche Scientifique (CNRS) and the laboratory in which the intellectual ideas behind the syntheses were established [1].

\section{References}

[1] C. Benhaoua, "New 1,2,3-triazole iminosugars derivatives using click chemistry," International Journal of Carbohydrate Chemistry, vol. 2012, Article ID 394574, 10 pages, 2012. 